\title{
THE PHYLOGENETIC SYSTEM OF THE GAYELLINI (HYMENOPTERA: VESPIDAE; MASARINAE)*
}

\author{
By James M. CARPENTER \\ Museum of Comparative Zoology, Harvard University, \\ Cambridge, MA 02138
}

\section{INTRODUCTION}

The Gayellini is one of the two tribes of Masarinae (Carpenter, 1981). Endemic to the Neotropics, the majority of the species are Patagonian, but one ranges as far north as Mexico. With ten described species, the group is far less speciose than its sister-tribe Masarini, which has over 200 described species (cf. Richards, 1962), and most species are rarely collected. These wasps have a very distinctive appearance among Vespidae (Fig. 1), and their taxonomic history has been more turbulent than any other higher vespid taxon. Although the phylogenetic placement of the group as a whole has now evidently been settled (Carpenter, 1981), no study has been made of the species. The current generic classification is fragmented, and there have been no keys to all of the taxa. In this paper, I investigate the phylogenetic relationships of the species, and present a revised generic classification along with keys to all taxa.

\section{TAXONOMIC HISTORY}

Saussure (1852-58) placed Gayella in the Section "Anomaloptères" of the "Euméniens" because the forewing recurrent veins $\left(\mathrm{m}-\mathrm{cu}_{1-2}\right)$ are received in separate cells (Fig. 6), as in the other genera placed in this section (Raphiglossa, and Stenoglossa $=$ Psiliglossa). In other vespids he studied both veins were received by the second submarginal cell. Ashmead (1902a) described the subfamily Raphiglossinae (in his Eumenidae) for this group, but by that time other genera had been described which had the diagnostic character of the recurrent veins. These were Euparagia and Paramasaris, both considered probable masarines by their authors (Cresson, 1879, and Cameron, 1901, respectively). Ashmead (1902b) proposed the tribe Euparagiini in his Masaridae for these two genera. So the recurrent

${ }^{*}$ Manuscript received by the editor September 28, 1988 
veins were no longer uniquely diagnostic. Bequaert (1918) questioned whether Gayella belonged in the Raphiglossinae, since the longitudinal plaiting of the forewings "is very obsolete" in the genus, and Bradley (1922) placed it in its own subfamily in Vespidae $s . l$. Bequaert (1928) transferred Paramasaris to this subfamily, based on its possession of the characteristic hindwing venation of Gayella (Fig. 3). Richards (1962) included the Gayellinae in his Masaridae, but his dendrogram showed Euparagiinae as more closely related to the subfamily Masarinae. I (Carpenter, 1981) demonstrated that Richards' Masaridae was a paraphyletic group, since Euparagiinae is the sister-group of Vespidae as a whole. Four synapomorphies were adduced which showed a sister-group relationship between gayellines and masarines: presence of hypostomal apodemes, loss of the midfemur basal ring, loss of the scutal lamella and provisioning with nectar and pollen. Gayellines and masarines were treated as tribes in an expanded Masarinae, the system followed here.

Gayella was originally described as monotypic for G. eumenoides by Spinola (1851). Saussure (1855 in Vol. 3 of Études), Willink $(1956,1963)$ and Willink and Ajmat de Toledo (1979) added five species. The latter paper provided a key to the six species, however I believe that the key given here will be easier to use. Paramasaris was also originally described as monotypic, for P. fuscipennis Cameron. Cameron (1904) later described a new genus Zethoides (non Zethoides Fox, 1899; Plesiozethus Cameron, 1905, and Metazethoides Schulz, 1906, are replacement names) for Z. flavolineatus, which differed from Paramasaris in having only two (Fig. 5), as opposed to three (Fig. 6), submarginal cells. Zavattari (1912) questioned whether Cameron had described this character correctly, and Bradley (1922) suspected that Plesiozethus was a synonym of Paramasaris. This was confirmed by Bequaert (1928), who showed that the number of submarginal cells was variable, and synonymized flavolineatus with fuscipennis. Giordani Soika (1974) described two new species in the genus, but provided no key. He also described a new genus, Paragayella, monotypic for the new species Paragayella richardsi. I consider this genus a synonym of Paramasaris, as discussed below. I also give the first key to species of the group.

\section{Materials AND Methods}

All of the species have been examined. Types of Paramasaris have been seen; treatment of Gayella follows Willink's concepts. Com- 


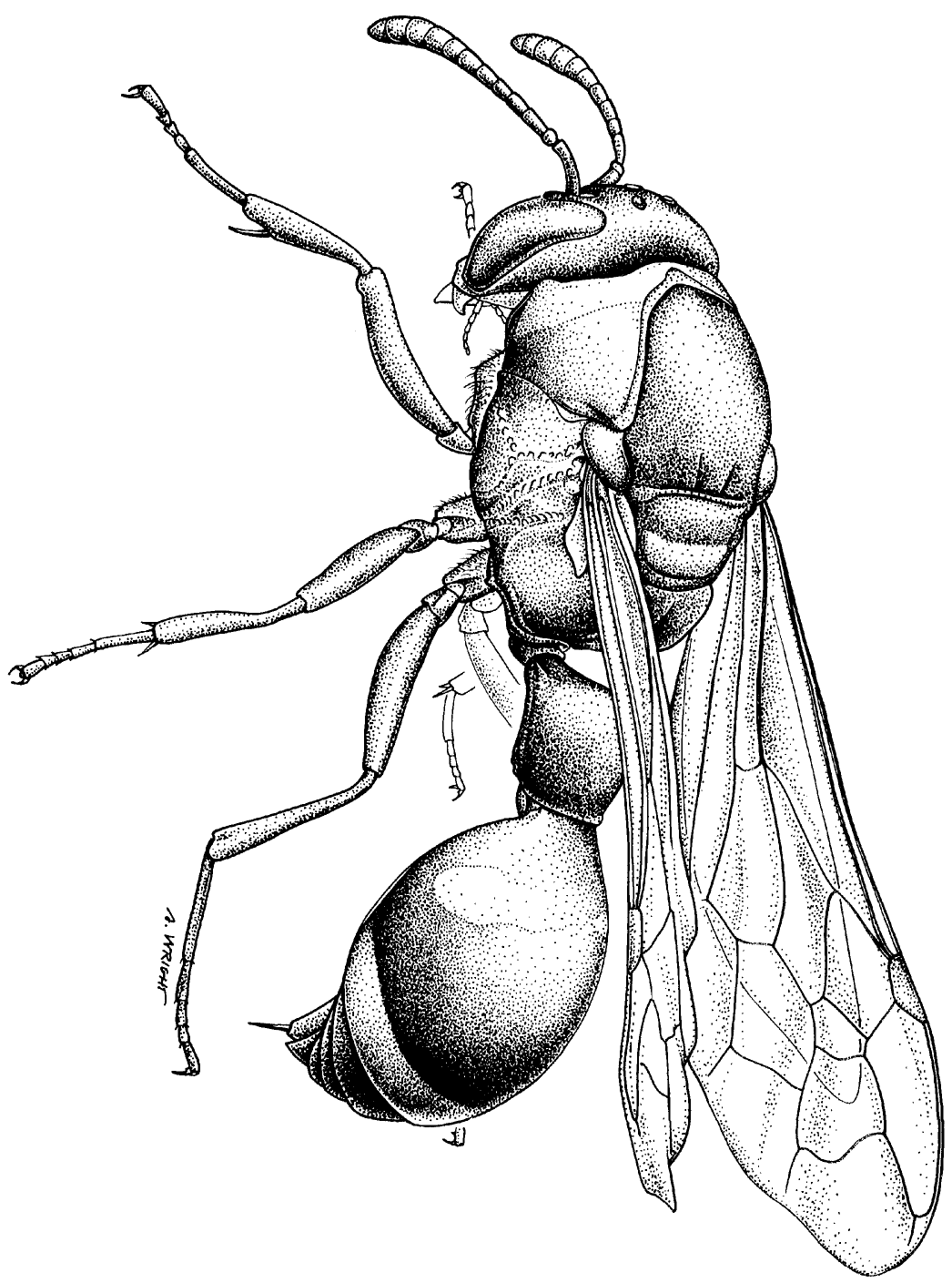

Fig. 1. Gayella eumenoides, ㅇ․ 
plete label data for all material of Paramasaris are listed under taxonomic notes for each species; for the relatively better known Gayella only provinces are noted. Acronyms for collections are listed below, along with the name of the individuals who provided the material where this was borrowed.

AMNH American Museum of Natural History, New York (M. S. Favreau)

BMNH British Museum of Natural History, London (M. C. Day, C. R. Vardy)

CAS California Academy of Sciences, San Francisco (W. J. Pulawski)

CP Charles Porter personal collection

IML Instituto Miguel Lillo, Tucuman (A. Willink)

IPC Instituto Pedagógico de Chile

MCZ Museum of Comparative Zoology, Cambridge

MF M. A. Fritz personal collection

MNHN Muséum National d'Histoire Naturelle, Paris

UCD University of California, Davis (P. S. Ward)

USNM U.S. National Museum of Natural History, Washington (A. S. Menke)

Morphological terminology follows Carpenter (1981), except that I have adopted Snelling's (1986) more descriptive terms "preoccipital" and "postocular" for the carinae previously termed "dorsal occipital keel" and "ventral occipital keel" (Richards, 1962). Detailed examination of the labiomaxillary complex and male genitalia was made by dissection of these structures, clearing slightly in cold lactophenol, and examination in glycerin. Measurements were made with an ocular micrometer. Illustrations were made with a Wild M-400 photomacroscope employing Kadak TMAX 400 film. Cladistic analysis (Hennig, 1966) was performed for all the features discussed in this paper. Outgroup taxa include Masarini and Euparagiinae, with reference to other Vespidae also occasionally made.

\section{RESULTS}

\section{Subfamily characters}

First I discuss some morphological features important in higherlevel vespid relationships, before turning to consideration of the phylogenetic relationships among the species. Autapomorphies of 


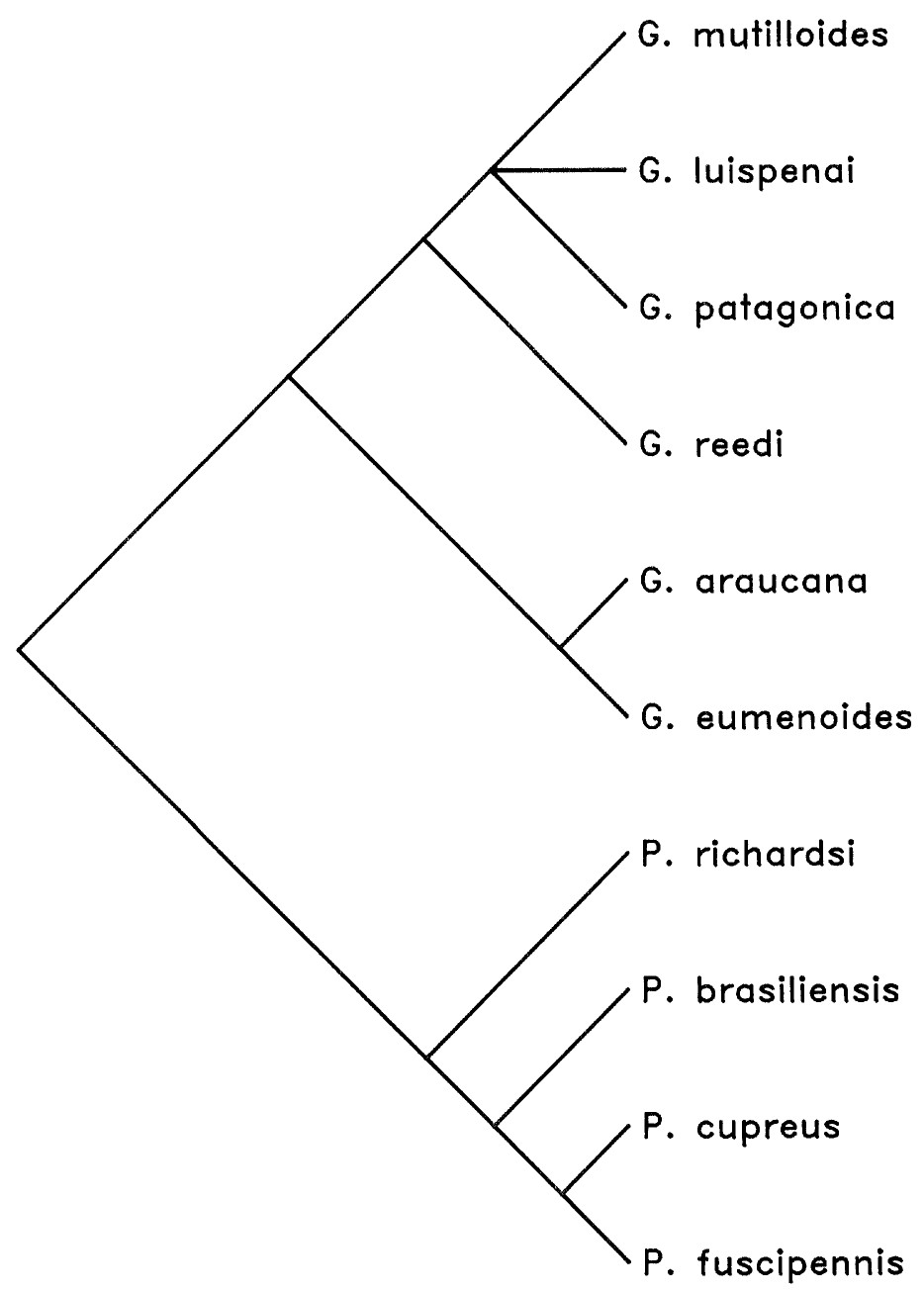

Fig. 2. Cladogram of the species of Gayellini. 
the Gayellini listed by Carpenter (1981) include the hindwing with $\mathrm{Cu}_{1}$ diverging from $\mathrm{M}+\mathrm{Cu}_{1}$ far distad of the insertion of cu-a (Fig. 3 ), the clypeus with the dorsal margin bisinuate (Fig. 12), the first metasomal tergum and sternum fused and metasomal segments after II retractile (the latter two convergent with other vespids). Some other autapomorphies are mentioned below.

Forewing discal cell. Carpenter (1981:14) noted that the discal cell is shorter than the submedian in Paramasaris. This is also the case in Gayella (Fig. 1), and this should be considered a reversion from the state of an elongate discal cell in other Vespidae (Fig. 4; $c f$. Carpenter, 1981), and thus an autapomorphy of Gayellini.

Forewing radial region. The variation in the number of submarginal cells in Paramasaris was alluded to above. Besides fuscipennis, I have seen loss of $\mathrm{r}-\mathrm{m}_{2}$ producing two submarginal cells in several specimens of brasiliensis (including the allotype and paratype, Fig. 5). The placement of $\mathrm{m}-\mathrm{cu}_{1}$ varies as well, sometimes meeting $\mathrm{M}$ at the fork where RS diverges. But this is not correlated with number of cells, and most specimens have the usual condition of RS diverging first (Figs. 5-6). In addition, the specimen of Paragayella richardsi from Formoso, Brazil, has a very small adventitious cell at the junction of $r-m_{3}$ and RS on one wing (Fig. 6), and both Goias specimens have an adventitious vein spur arising from the middle of $\mathrm{r}-\mathrm{m}_{3}$ (Fig. 6).

Clypeus. The clypeus is narrower than its height in all species, particularly in males (Figs. 11-17). Richards (1962:46) stated that the reverse is true in Paramasaris, perhaps a lapsus. This is not the usual state in Vespidae, and is perhaps apomorphic, although the degree of narrowing varies in the tribe.

Occipital carinae. Gayellini have both the postocular and preoccipital carinae in the groundplan, contrary to Richards (1962:12). The postocular carina is reduced in length, and may be present only as a trace just ventral to the eye in Gayella, but is typically obvious in the eumenoides group. The carinae are almost confluent in many specimens of eumenoides and araucana, separated by only a slight gap (Fig. 18). The "complete" carina in Paramasaris (Richards, 1962:46; Fig. 19) is evidently produced by confluence of the postocular with the preoccipital carina, as occurs in some Masarini (Snelling, 1986) and probably other Vespidae (Carpenter, 1988). The postocular carina is effaced in Paragayella (Fig. 20). 

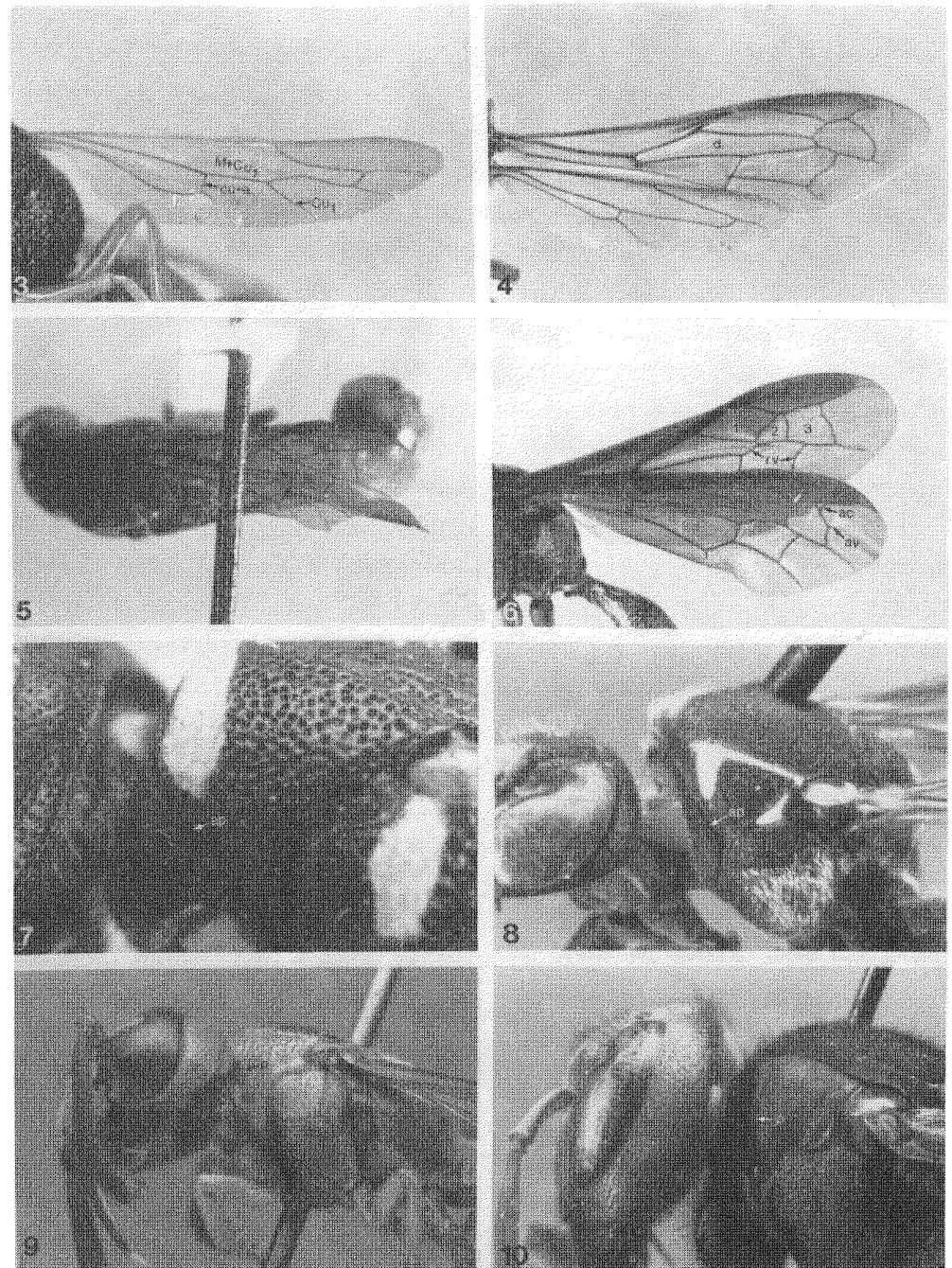

Figs. 3-10. 3. Gayella araucana, $7 \times$. Hindwing. 4. Paragia decipiens aliciae, $4 \times$. Wings. 5- 6. Wings, $6 \times$. 5. Paramasaris brasiliensis. 6. P. richardsi. Submarginal cells are numbered. 7-10. Lateral view of pronotum. 7. G. araucana, 17X. 8. Euparagia scutellaris, $10 \times$. 9. Ischnocoelia robusta, $6 \times$. 10. Vespa affinis, $5 \times$. ac: adventitious cell; ap: anterior pronotal carina; av: adventitious vein; $d$ : discal cell; $f$ : pronotal fovea; $p$ : pronotal carina; $r v$ : recurrent veins. 
Acroglossal buttons. As noted by Carpenter (1981), Richards (1962) incorrectly stated that acroglossal buttons are lacking from the ligula of Gayellini. The only species in which they are entirely lacking are Paramasaris fuscipennis and cupreus (Fig. 21). These structures are also absent from the glossa of Paramasaris brasiliensis, but are present on the paraglossae. This is a transformation series in reduction. Other gayellines have the buttons on both the glossa and paraglossae (Fig. 22), including Paragayella richardsi, the sister-group of Paramasaris, and P. brasiliensis is the sistergroup of fuscipennis + cupreus (Fig. 2).

Hypostomal apodemes. These are present in all species, which supports the interpretation of synapomorphy with Masarini. They are always very narrow (Fig. 23).

Pronotal carina. Paramasaris and Paragayella are notable for having two parallel carinae on the pronotum. One is present at the anteroventral margin of the pronotum; the other is posterior to this and runs towards the humeri and dorsum of the pronotum (Figs. 29-31, 40). The second carina shows a transformation series in development, ranging from short lateral sections only (Paragayella, Figs. 24, 29), to extending to the dorsum (Paramasaris brasiliensis, Figs. 25, 30), to complete across the dorsum ( $P$. cupreus and fuscipennis, Fig. 26). This series apparently corresponds to the phylogenetic relationships among these species (Fig. 2). Gayella has only the anterior carina (Fig. 7). Euparagiinae also has only the anterior carina (Fig. 8), although the humeri are somewhat raised in scutellaris. In Masarini the anterior carina is usually blunt, and a lateral carina on the humeri may be present (Fig. 37). In all these groups, the anterior carina precedes a groove which is frequently crenate (secondarily reduced in various Masarini).

The situation is different in other Vespidae. In Polistinae, the structure termed the "pronotal prominence" (Richards, 1978) is probably homologous with the anterior carina. Although often blunt, it is frequently carinate, and lies at the anteroventral margin of the pronotum (Fig. 38). It precedes the pronotal fovea, which is sometimes set in a deep depression; there is no lateral groove. In the groundplan, there is also a carina on the dorsum (Carpenter, 1989). This second carina is usually quite short laterally, and may closely approach the anterior carina (Fig. 38). In Polistes the second carina extends almost to the ventral pronotal margin in many species, and the fovea, which is anterior to this carina, is not preceded by a 

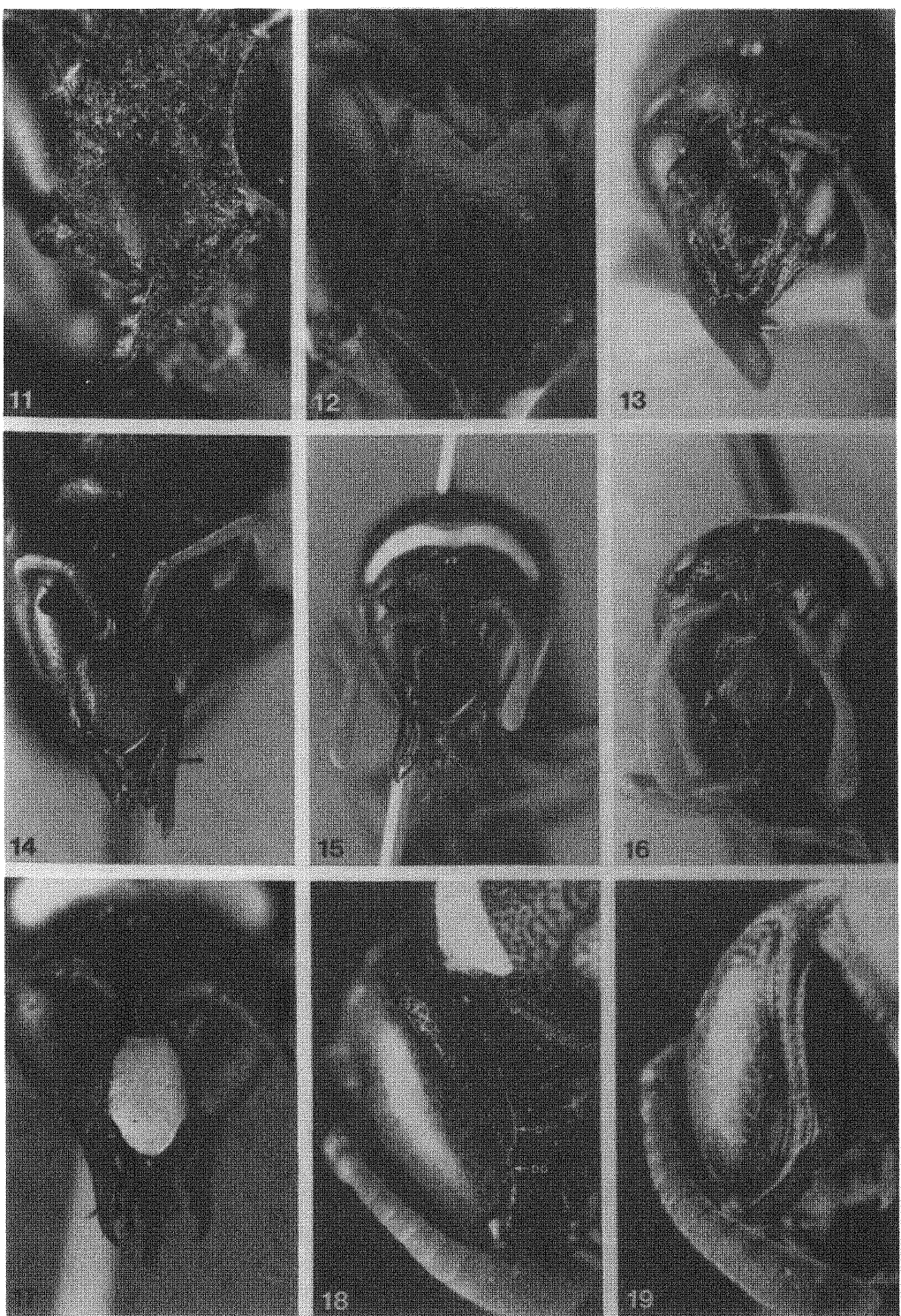

Figs. 11-19. 11-12. Clypeus, ․ 11. Paramasaris richardsi, 19X. 12. P. brasiliensis, 27X. 13-16. Frontal view of head, ㅇ. 13. P. cupreus, 14X. 14. Gayella mutilloides, $5 \times$. 15. G. eumenoides, $7 \times$ 16. G. araucana, 10×. 17. G. reedi ô, 10×. Frontal view of head. 18-19. Lateral view of head. 18. G. araucana $15 \times$. 19. $P$. brasiliensis, $21 \times$. $c c$ : apical clypeal carinae; $g$ : gap between mandibular teeth; po: postocular carina; $p r$ : preoccipital carina. 
"prominence" (Fig. 39). Richards (1973) confused the dorsal carina in Polistes, behind the fovea, with the anterior carina in other polistines, in front of the fovea. Eumeninae, which also have a fovea, also have a carina in front of the fovea (Fig. 9), which continues across the dorsum in the groundplan (Carpenter and Cumming, 1985). The single carina may be a composite structure, derived from a state resembling certain polistines with two closely approximated carinae (Fig. 38). This is also the case in the groundplan of Vespinae (Carpenter, 1987), where there is a single carina, preceding the pronotal fovea and running across the dorsum (Fig. 10). Stenogastrinae have a highly modified pronotum and lack a posterior carina and fovea (Carpenter, 1988), but have a blunt ridge anteriorly that may correspond to the anterior carina (Fig. 32).

Thus, an anterior carina is clearly an ancestral vespid character, but considering its diverse form, the posterior carina may have evolved multiple times. The alternative interpretation, that it evolved once (in the ancestor of all vespids except Euparagiinae), requires secondary losses within Gayellini (Paragayella, Paramasaris and Gayella independently) and Stenogastrinae. The interpretation of nonhomology is more parsimonious, and accords with the apparent transformation series in Paramasaris. In any case, the separate posterior carina has also been lost on numerous occasions within the Masarini and Polistinae (Carpenter, 1989, and in prep.), and the possibly composite carina has also been lost several times within Eumeninae and Vespinae (Carpenter, 1987; Carpenter and Cumming, 1985). Secondary loss also applies to the pronotal fovea, present in the groundplan of Eumeninae, Polistinae and Vespinae. It has been lost multiple times within Polistinae (Richards, 1978; Carpenter, 1989), and probably also in Stenogastrinae. Presently available morphological and behavioral evidence supports a sistergroup relationship between Stenogastrinae and Polistinae + Vespi-

Figs. 20-28. 20. Paramasaris richardsi, 17X. Lateral view of head. 21-22. Ventral view of ligula. 21. P. fuscipennis, $25 \times$. 22. Gayella luispenai, 16×. 23. G. mutilloides, $14 \times$. Ventral view of head, mouthparts removed. 24-28. Dorsofrontal view of pronotum. 24. P. richardsi, $9 \times$. 25. P. brasiliensis, 11X. 26. P. cupreus, $13 \times$. 27. G. eumenoides $\hat{\delta}, 10 \times$. 28. G. araucana $9,8 \times$. ab: acroglossal buttons; $a p$ : anterior pronotal carina; $g l$ : glossa; $h$ : hypostomal apodeme; $h p$ : humeral projection; pg: paraglossa; $p l p$ : posterior lingual plate; $p p$ : posterior pronotal carina; $p r$ : preoccipital carina. 

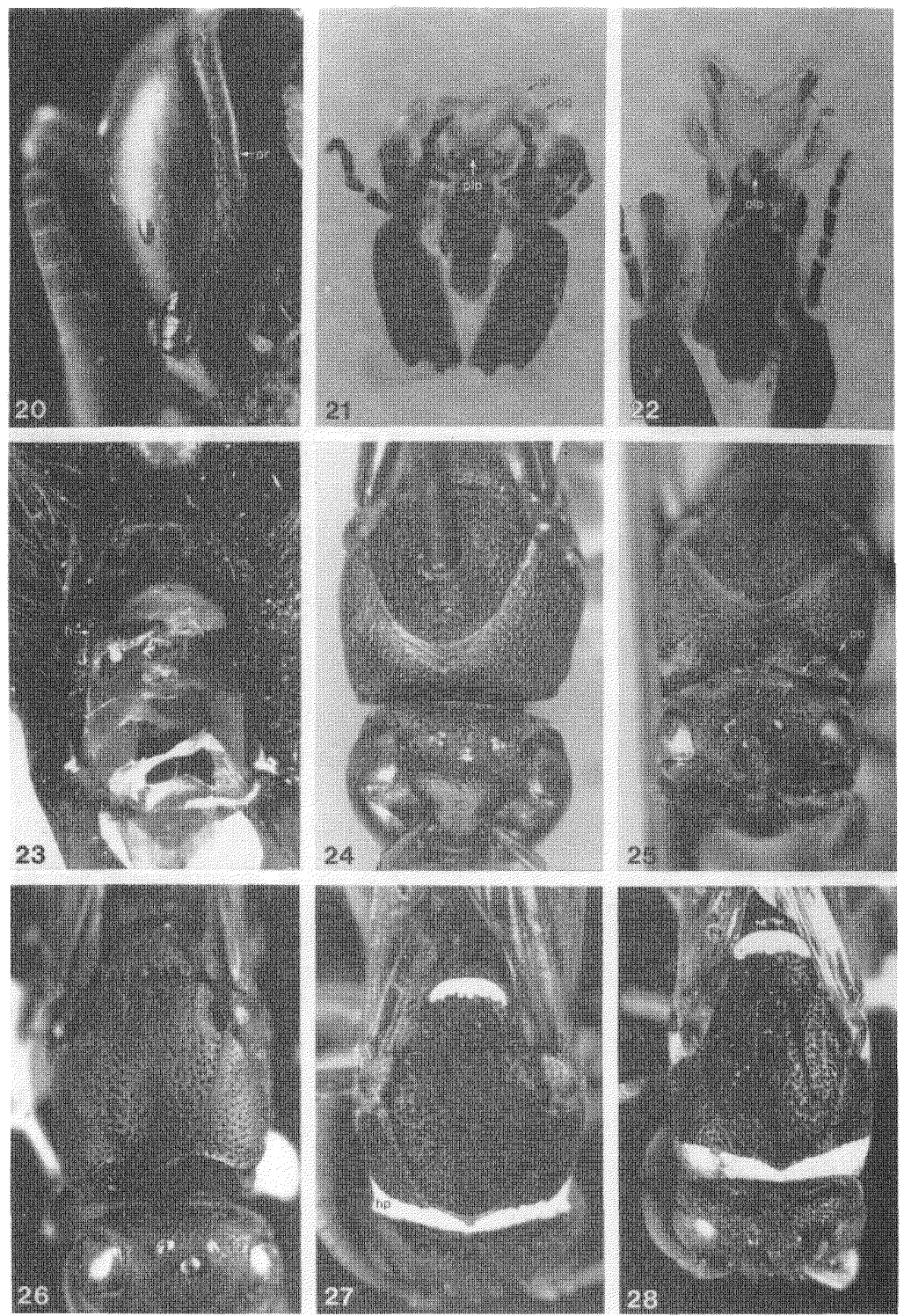
nae (Carpenter, 1981, 1988, 1989), thus requiring an inference of loss in Stenogastrinae.

Hind coxal carina. Richards (1962) made contradictory statements concerning the presence of this feature in Gayellini (cf. p. 15 and 44). This was initially followed by Carpenter (1981), but corrected by Carpenter and Cumming (1985:907). All Gayellini lack this carina, a primitive condition.

Claws. Richards (1962:44) erroneously characterized the claws of Gayella as simple, and Carpenter (1981:26) initially followed this (corrected in Carpenter and Cumming, 1985:907). In fact, the claws are toothed in all species of Gayellini (variable in G. mutilloides). This is the plesiomorphic condition in Vespidae.

Male genitalia. I have examined the genitalia of all species except Paramasaris cupreus and Paragayella richardsi, where the males are still unknown. In the groundplan of the tribe, the aedeagus is broadly rounded apically, the digitus is a prominent triangular lobe that is desclerotized ventrally, the cuspis is a small lobe completely fused to the lamina volsellaris, and the parameral spines are long and sharply pointed (Figs. 56-63). Figure 39 of Richards (1962), showing a large, triangular cuspis and rounded digitus in Gayella araucana, is incorrectly labelled. What is there termed cuspis is actually the digitus, and the structure labelled as digitus must be the aedeagus ( $c f$. Fig. 58). This figure was the reason I previously was unable to characterize the groundplan of the volsella in the tribe (Carpenter, 1981:26), as I had not seen that species at the time. Within genera, the genitalia are relatively uniform, with species differing in details (especially of the volsella); however, there are some consistent differences between the genera. These are discussed below.

\section{Paramasaris}

Giordani Soika (1974) characterized Paragayella as related to Gayella, and stated (my translation): "This genus appears at first sight a Gayella by the general aspect and dimensions." The type material I have seen he even labelled as "Gayella richardsi." In fact, Paragayella is not really even superficially similar to Gayella. Paragayella lacks some of the apomorphies shared by the species of Paramasaris, and for some other derived traits which Paramasaris and Paragayella share the latter has a less developed state. Thus it shares some primitive similarity with Gayella, which of course indi- 
cates nothing about phylogenetic relationship (Hennig, 1966). On the other hand, Paragayella shares several clear synapomorphies with Paramasaris. These include the forewing with $\mathrm{r}-\mathrm{m}_{3}$ more or less straight (Figs. 5-6; sinuous in Gayella and other Vespidae, Figs. 1, 4), the pronotum with two carinae (Figs. 29-31, 40; one in Gayella Fig. 7), the metanotum with a longitudinal median carina (Figs. 33, 46; none in other Masarinae), and the metasoma petiolate (tergum I in dorsal view at least twice as long as wide and half the width of tergum II, Figs. 35, 40-41; it is differently shaped in Euparagiinae, Masarini and Gayella, Figs. 1, 43-45). Paragayella is the sistergroup of Paramasaris. Autapomorphies of Paragayella include the reduced postocular carina (Fig. 20) and the transversely carinate metanotum (Fig. 46).

The three species of Paramasaris share numerous synapomorphies. The postocular and preoccipital carinae are apparently confluent (Fig. 19). These carinae are separated in other Gayellini, and the postocular carina reduced in several species (Paragayella, the Gayella mutilloides group). The mandibles are tridentate with the proximal teeth separated from the apical one by a gap (Fig. 13). The mandibles are quadridentate in females of Paragayella and Gayella (Figs. 11, 14-15), and tridentate in males of the latter (Fig. 17; Richards, 1962:44, erroneously characterized the mandibles of Paramasaris as quadridentate and those of Gayella as simple); there is no gap. Quadridentate mandibles is the groundplan state of most of the Vespidae (Carpenter, 1981), although Euparagiinae has bidentate mandibles. The glossa is shortened and lacks acroglossal buttons, the paraglossae are broadened, and the posterior lingual plate is cordate in shape (Fig. 21). The posterior lingual plate is slightly broadened in other gayellines, but the length of the structure still exceeds its width (Fig. 22). The clypeus is broadly truncate (Fig. 12), which is here treated as derived, convergent with the groundplan of Masarini. Paragayella has the clypeus narrowly truncate (Fig. 11), as in Euparagiinae, which is considered the primitive state. A broad truncation seems most simply interpreted as derived from a narrow emargination, as does the pointed clypeus of Gayella (Figs. 14-17). The posterior carina of the pronotum extends further dorsad in Paramasaris (Figs. 25-26) than Paragayella (Fig. 24), a further apomorphic development. The propodeum has oblique carinae more or less developed (Figs. 31, 33), a unique trait in 

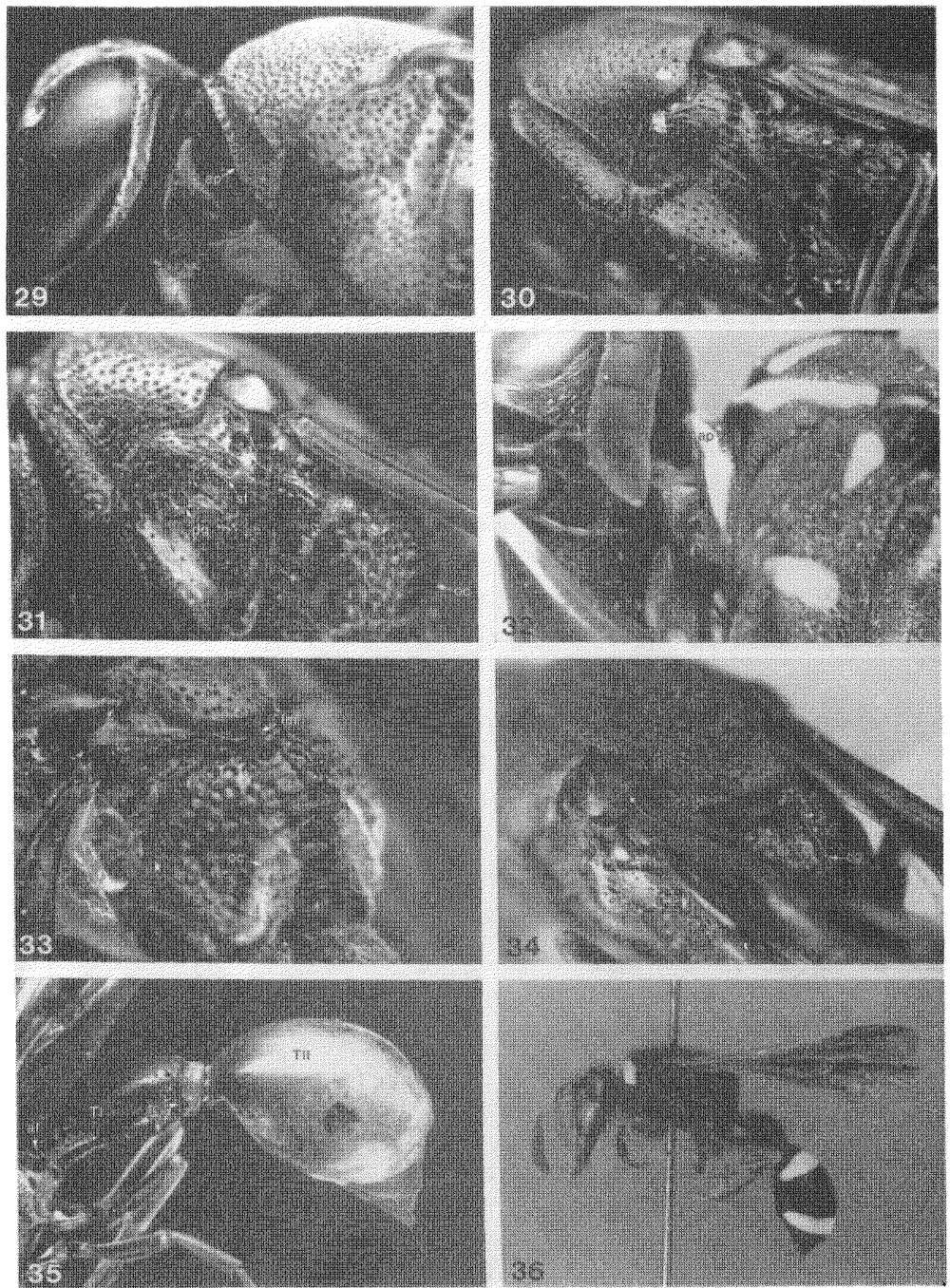

Figs. 29-36. 29-32. Lateral view of pronotum and mesepisternum. 29. Paramasaris richardsi, $13 \times$. 30. $P$. brasiliensis, 14×. 31. $P$. fuscipennis, $17 \times$. 32. Parischnogaster mellyi, 16×. 33-34. Oblique lateral view of propodeum. 33. P. fuscipennis, 17×. 34. P. cupreus, 15×. 35. P. brasiliensis holotype, 9X. Lateral view of metasoma. 36. Gayella reedi $\hat{\delta}, 3 \times$. Lateral view. ap: anterior pronotal carina; at: anterior truncation of metasomal tergum I; $\mathrm{cg}$ : carina delimiting 
Masarinae. The first metasomal tergum has a blunt posterior ridge that is continued anterolaterally and drawn out into projections posterolaterally (Figs. 35, 40), a feature unique in Vespidae. The tergum is also strongly truncate anteriorly (Fig. 35). The second tergum has a median longitudinal ridge (Figs. 40, 42), which however is variably developed in brasiliensis (strong in the male and not developed in the female, Fig. 35). A longitudinal ridge is found elsewhere in Vespidae only within Eumeninae (Cyphomenes, where it is anterior). Finally, the parameral spines of the male genitalia are extremely elongate in brasiliensis and fuscipennis, being longer than the parameres and extending far beyond the apex of the aedeagus (Fig. 56). This is apparently a derived condition; in Gayella, Euparagiinae and Masarini the spines are shorter than the parameres and extend little beyond the aedeagus (Figs. 57-63). Males of cupreus are predicted to share this synapomorphy, and possibly also Paragayella.

Within Paramasaris, cupreus and fuscipennis are sister-groups. This is shown by the paraglossae also lacking acroglossal buttons (Fig. 21), the female clypeus with a pair of short apical carinae (Fig. 13), the second carina of the pronotum more complete dorsally (Fig. 26), and the longitudinal carina on tergum II well developed in females (Figs. 40, 42). Autapomorphies of the species are: for cupreus the propodeal median groove delimited by more lamellate carinae (Fig. 34); for fuscipennis the oblique propodeal carina better defined (Fig. 33), and the dorsal groove and scrobal furrow of the mesepisternum broader and deeper (Fig. 31, cf. with 29-30, 40). I have not discovered any autapomorphies of brasiliensis.

Since Paragayella is the sister-group of Paramasaris, recognition of both genera is consistent with monophyly. However, it serves little useful purpose. Paragayella itself has few apomorphies-it mostly lacks those of Paramasaris. Recognition of Paragayella thus contributes little to the process of efficient diagnosis. Since Paragayella is monotypic, and Paramasaris consists of but three

propodeal median groove; $d g$ : dorsal groove; $l m$ : longitudinal metanotal carina; $o c$ : oblique propodeal carinae; $p p$ : posterior pronotal carina; $s f$ : scrobal furrow; TI: metasomal tergum I; TII: metasomal tergum II; $t c$ : posterolateral tergal projection. 

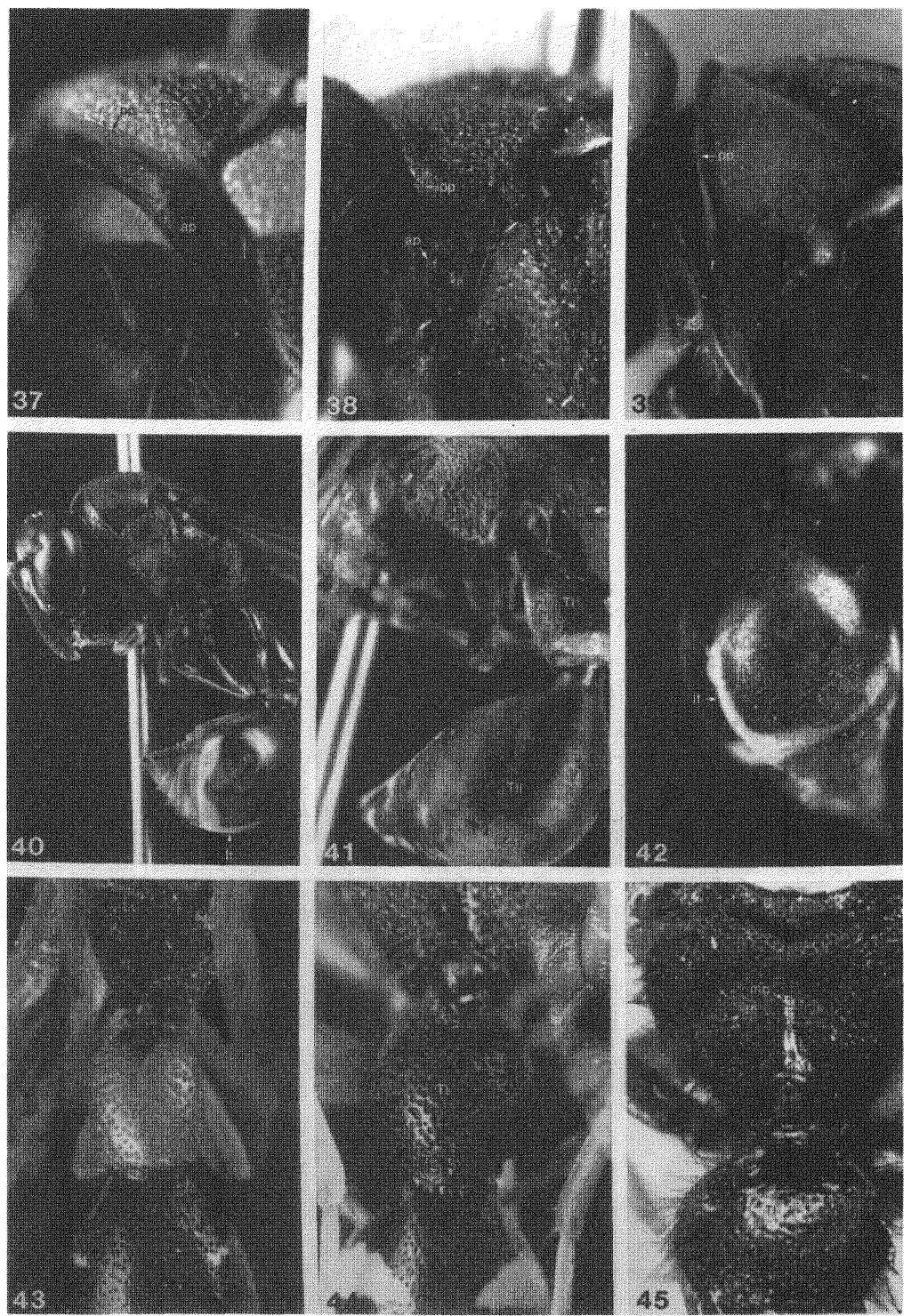

Figs. 37-45. 37-39. Lateral view of pronotum. 37. Metaparagia doddi holotype, 13×. 38. Parachartergus apicaloides, 13×. 39. Polistes anduzei, 10×. 40. Paramasaris cupreus $6 \times$. Lateral view. 41. P. richardsi, $8 \times$. Oblique dorsal 
species, recognition of Paragayella is but another example of the current needless fragmentation of vespid generic classification, which I have decried elsewhere (Carpenter and Cumming, 1985; Carpenter, 1987, 1988). A fully sequenced cladistic classification (Wiley, 1979) is possible with a single genus. I am therefore synonymizing Paragayella with Paramasaris.

\section{Gayella}

The monophyly of the genus is shown by the pointed clypeus (Figs. 14-17; not similar to that of Stenogastrinae and Polistinae), the temples projecting somewhat and the emarginate and bispinose last metasomal tergum (Figs. 50-52). In other Masarinae and Euparagiinae the clypeus is truncate or emarginate, the temples do not project and the last visible metasomal tergum is neither emarginate nor spined. Several characters of the male genitalia are also synapomorphies. The digitus is enlarged relative to Paramasaris (cf. Figs. 56 and 57-63), the cuspis is tuberculate basally (Figs. 57-61, 63), and the paramere has an enlarged lobe (dorsal to the spine, Fig. 62). The combination of features of the male genitalia is unique in Vespidae. Finally, the globose shape of the first metasomal tergum may be apomorphic, but this is variable within the genus (Figs. 43-45).

Within the genus, two monophyletic species groups may be recognized, which allows a classification that is phyletically sequenced (Wiley, 1979). These are the eumenoides group, for eumenoides and araucana, and the mutilloides group, inlcuding reedi, patagonica, luispenai and mutilloides.

\section{Eumenoides group}

The monophyly of the eumenoides group is established by the tegula, which lacks the short posterior lobe found in Paramasaris and the mutilloides group (cf. Figs. 47 and 48). This feature is approached in reedi (Fig. 49), diminishing its strength. The projection from the cuspis is tuberculate and apical relative to that

view of metasomal terga I and II. 42. P. fuscipennis, 13X. Lateral view of metasomal tergum II. 43-44. Dorsal view of $\hat{\delta}$ metasomal tergum I, 10X. 43. Gayella araucana. 44. G. eumenoides. 45. G. luispenai $+10 \times$. Posterodorsal view of propodeum and metasomal tergum I. ap: anterior pronotal carina; $f$ : pronotal fovea; lt: longitudinal carina of metasomal tergum II; $m g$ : propodeal median groove; pp: posterior pronotal carina; TI: metasomal tergum I; TII: metasomal tergum II. 

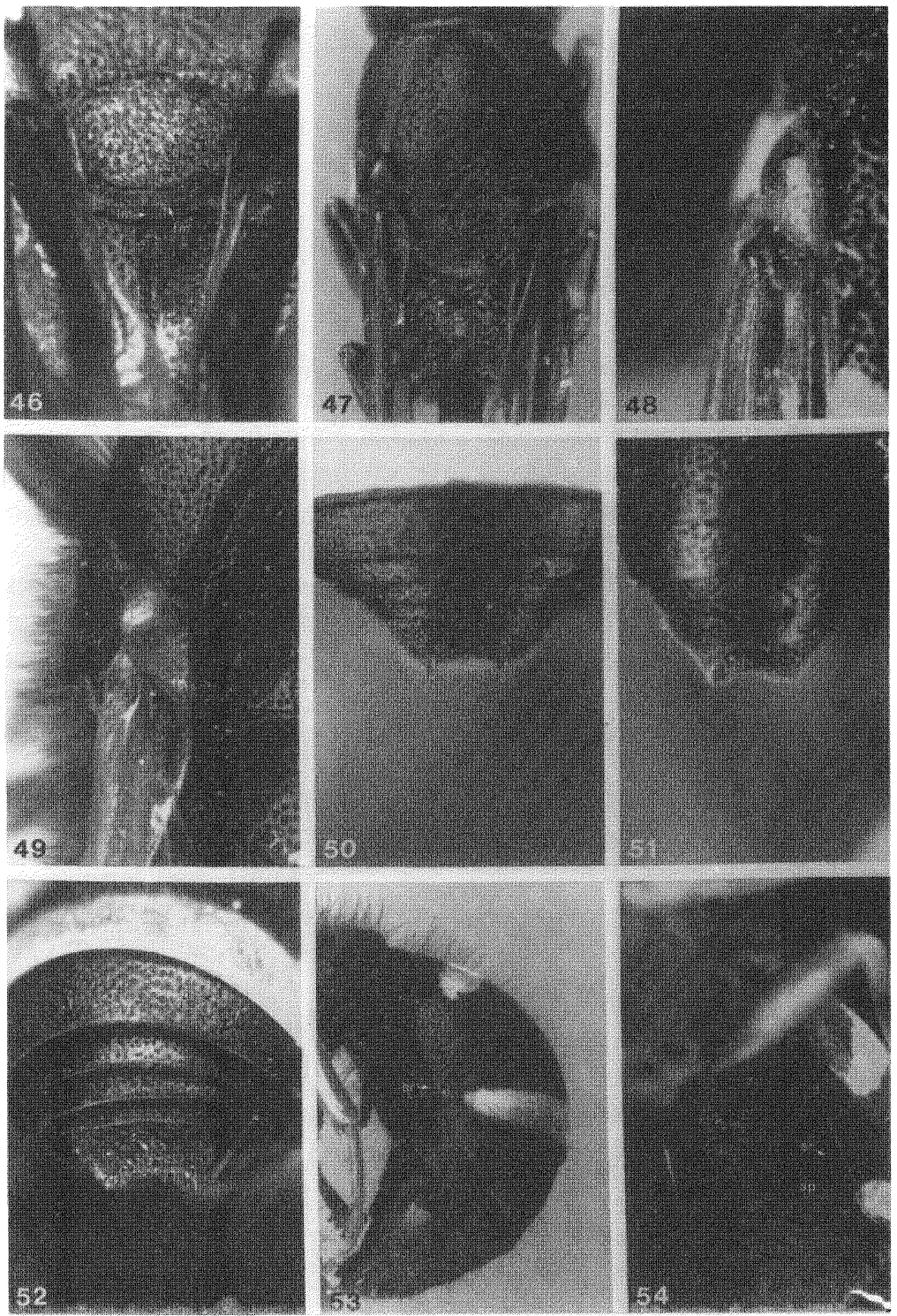

Figs. 46-54. 46. Paramasaris richardsi, 14X. Dorsal view of scutellum and metanotum. 47. P. cupreus, $13 \times$. Dorsal view of mesosoma. 48-49. Tegula. 48. Gayella araucana, $21 \times$. 49. G. reedi, $15 \times$. 50-52. Dorsal view of $\hat{o}$ metasomal 
in the mutilloides group (cf. Figs. 57-58 and 59-61, 63), and is here inferred as an elaboration. A sister-group relationship therefore obtains between eumenoides and araucana. The first has the autapomorphy of the humeri projecting above the anterior pronotal carina (Fig. 27). A very weak angle is also found in reedi, and Paramasaris has an angle of a different form (Fig. 24), but the projection is much stronger in eumenoides. Willink and Ajmat de Toledo (1979: fig. 3) depict eumenoides as having an apically bilobed aedeagus; however the shape varies among specimens in my dissections, and most have a broadly rounded apex as in other Gayella (Fig. 57). The sister-species of eumenoides, araucana, also has some autapomorphies. The acroglossal buttons are very reduced in size in the male, whereas they are elongate in the female and other Gayella. The pronotal punctation in araucana is relatively coarser than in the rest of the tribe, so this may also be a derived feature. The margins of the pronotum are more or less subparallel in araucana and more convex in other Gayella (cf. Figs. 27 and 28), but the difference from eumenoides is slight. The first metasomal tergum is narrower than in other species of the genus (cf. Figs. 43 and 44-45), but this is approached in some specimens of eumenoides. The male genitalia has the cuspis with the basal tubercle sharply pointed (Fig. 58). The tubercle is usually less pointed in eumenoides (Fig. 57), but some specimens approach araucana. Willink and Ajmat de Toledo (1979: fig. 5) depict a rather different digitus in araucana. However, their figures were evidently drawn from specimens flattened on slides, and do not accurately portray the relative uniformity in this structure (or the aedeagus) among the species (Figs. 57-63).

\section{Mutilloides group}

The most obvious feature supporting the monophyly of the mutilloides group is the coat of elongate black hairs (Figs. 36, 45, 53). This trait can be an ecological correlate in other vespids, being found for example in species of Hypodynerus (Eumeninae) sympatric with Gayella. Members of the mutilloides group share other

tergum VII. 50. G. reedi, 17×. 51. G. araucana, 20×. 52. G. eumenoides, 17×. 53. G. patagonica $\hat{\delta}, 7 \times$. Lateral view of metasoma. 54. G. luispenai $\hat{\delta}$, $8 \times$. Oblique ventral view of metasomal sternum II. $l m$ : longitudinal metanotal carina; $s p$ : sternal ridge projection; $s r$ : posterolateral ridge of metasomal sternum II; $t m$ : transverse metanotal carina. 
derived features, however. The preoccipital carina is evanescent and separated from the postocular carina by more than an ocellar diameter in species of this group, whereas both are well developed and closely approximated in the eumenoides group and Euparagiinae. The femur is punctate in the mutilloides group; it is smooth in other gayellines. The spines defining the emargination of the last visible metasomal tergum are narrow and elongate in the mutilloides group (Fig. 50), whereas they are broader and shorter in the eumenoides group (Figs. 51-52). Since both states uniquely characterize monophyletic groups, the polarity cannot be clearly inferred. However, the state of the metasomal spines in the mutilloides group is a more extreme development, and is here suggested as relatively apomorphic.

Within the group, reedi is the sister-group to the remaining three species. I have not discovered any clear autapomorphies of this species. Synapomorphies uniting patagonica, mutilloides and luispenai include greater development of the long black hairs on the metasoma (extending over the disc of tergum II, Fig. 53), and an elongate malar space (length $1 / 2$ to greater than the width of the interantennal distance, Fig. 14; shorter than this in other gayellines, Figs. 15-17). The postocular carina tends to be more effaced (as in Fig. 20), but traces appear to be present in some specimens. Metasomal sternum II in the male and to some extent also the female is bordered posterolaterally with blunt ridges (Figs. 53-54), however these are variably developed in patagonica, and reedi approaches this condition. Among these three species, the features I have polarized are autapomorphies. Hence, the relationships are at present unresolved (Fig. 2). Autapomorphies of the species are: for mutilloides the very long malar space (Fig. 14), the acroglossal buttons more elongate and the glossa more deeply bifid than other Gayella, and the cuspis tubercle quite blunt (Fig. 61); for luispenai the male metasomal sternum II projections elongate (Fig. 54); and for patagonica the female propodeal median groove narrowed before broadening dorsally (Fig. 55; smoothly narrowed in other Gayella, Fig. 45).

\section{IDENTIFICATION KeYS}

\section{Genera}

1. Pronotum with two transverse carinae (Figs. 29-31); clypeus emarginate to truncate (Figs. 11-13); last tergum neither 
emarginate nor bispinose apically ... Paramasaris Cameron

- Pronotum with one carina (Fig. 7); clypeus pointed or rounded (Figs. 14-17); last tergum widely emarginate and bispinose apically (Figs. 50-52) .......... Gayella Spinola

\section{Paramasaris}

1. Pronotum with posterior carina extending no further dorsad than anterior carina (Fig. 24); head with carina not extending from vertex to mandibular base (Fig. 20); propodeum without oblique carinae (Fig. 41) (Brazil) ... . richardsi (Giordani Soika)

- Pronotum with posterior carina extending much further dorsad than anterior carina (Figs. 25-26); head with carina extending from vertex to mandibular base (Fig. 19); propodeum with oblique carinae (Fig. 33) ...............

2. Pronotum with posterior carina incomplete dorsally (Fig. 25); female clypeus without lateral carinae (Fig. 12) (Argentina, Brazil) ............... brasiliensis Giordani Soika

- Pronotum with posterior carina continuous dorsally (Fig. 26); female clypeus with lateral carinae (Fig. 13) ............

3. Propodeum with median groove delimited by carinae which are higher than the adjacent areolae (Fig. 34); mesepisternum with dorsal groove narrower, shallow (Fig. 40) (Colombia, Peru) .................... cupreus Giordani Soika

- Propodeum with median groove not delimited by carinae which are higher than adjacent areolae (Fig. 33); mesepisternum with dorsal groove broad, deep (Fig. 31); (Colombia to Mexico) .................... fuscipennis Cameron

Gayella

1. Thorax and metasoma with short, sparse whitish pubescence

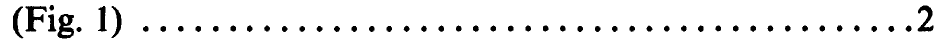

- Thorax and at least TI, TII basally and sterna with long, thick

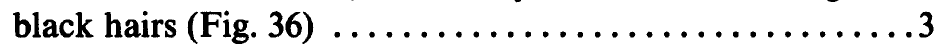

2. Pronotum rounded laterally (Fig. 28)...... araucana Willink

- Pronotum angled laterally (Fig. 27) .... eumenoides Spinola

3. Malar space as long as width of interantennal distance (\$, Fig. 14) or longer ( $\left.\hat{\delta}^{\dagger}\right) \ldots \ldots \ldots \ldots \ldots \ldots$ mutilloides Saussure

- Malar space less than the width of the interantennal distance

4. TII with long hairs only anteriorly, posterior terga without long hairs (Fig. 36) ................. reedi Willink 
- TII with long hairs extending to apex, posterior terga densely haired (Fig. 53) ............................

5. Male SII with blunt posterior projections (Fig. 54); female with propodeal median groove narrowing dorsally (fig. 45) ..................... luispenai Willink \& Toledo

- Male SII without projections (Fig. 53); female with propodeal median groove narrowed ventrally before broadening dorsally (Fig. 55) ..................... patagonica Willink

\section{TAXONOMIC NOTES}

Tribe Gayellini Bradley, 1922

Genus Paramasaris Cameron, 1901:311. Type species Paramasaris fuscipennis Cameron, 1901. Monotypic.

Zethoides Cameron, 1904: 93. Type species Zethoides flavolineatus Cameron, 1904. Monotypic. Non Zethoides Fox, 1899.

Plesiozethus Cameron, 1905:269. Replacement name for Zethoides Cameron.

Metazethoides Schulz, 1906:213. Unnecessary replacement name for Zethoides Cameron.

Paragayella Giordani Soika, 1974:87, 89, 99. Type species Paragayella richardsi Giordani Soika, 1974. Original designation. NEW SYNONYMY.

\section{Paramasaris richardsi (Giordani Soika), NEW COMBINATION}

Paragayella richardsi Giordani Soika, 1974:101, fig. 2, pl. II, 우 (BMNH) - "Brasile: Mato Grosso, Serra Roncados, R. S. Base Camp."

In his description, Giordani Soika referred to 13 specimens; however I have seen only four specimens in the British Museum. The holotype is on a pin with a paratype, which is not mentioned in the description. The holotype label is above the paratype label, and so the upper specimen is presumably to be treated as the holotype.

In addition to the material in the British Museum, I have seen female specimens from the following localities in Goias in Brazil: "24 kil. E. Formoso, June 6, 1956 (F. S. Trúxal)" UCD; "S. Isabel do Morro, Ilha do Bananal, June 1961 (M. Alvarenga)" MCZ. 


\section{Paramasaris brasiliensis Giordani Soika}

P. brasiliensis Giordani Soika, 1974: 105, 우 $\widehat{\text { (type }}$ † MCZ) -_Brasile: Nova Teutonia, Santa Catarina."

Giordani Soika cited the holotype and allotype as deposited in the USNM, but both are in fact in the $\mathrm{MCZ}$, along with the paratype collected on I-1967. I have seen additional specimens, both in the collection of UCD, from "Brazil: Nova Teutonia, Santa Catarina, I 1965 (F. Plaumann)"; and "Argentina: Haut Parana, Thu-Cuare prés San Ignacio, 1911 (E. R. Wagner)”.

\section{Paramasaris cupreus Giordani Soika}

P. cupreus Giordani Soika, 1974: 106, ㅇ (BMNH)-“Columbia: Caqueta, Florencia, 480 m."

Besides the holotype one of the paratypes mentioned by Giordani Soika is in the British Museum. New localities in Colombia include: "Putumayo, Mocoa, 30.X.1974 (M. Cooper)" now in the MCZ; "Dept. Magdalena, Socorpa Mission, Sierra de Perija, VIII.525.1968 (Borys Malkin)" 3 O AMNH and MCZ. One of the Magdalena specimens is labelled " $1500 \mathrm{~m}$." The specimen from Mocoa has a label reading "collecting mud in forest." I have also seen a specimen from "Peru: Loreto, Pucallpa 10.iv.1965 (J. M. Schunke)" BMNH.

Giordani Soika (1974) alluded to various differences in sculpture between cupreus and fuscipennis in his description, but several of these do not hold up in the additional material I have seen. The pronotal carina and tergal punctation are similar in most specimens, and the clypeus is not more narrowly emarginate in cupreus. The finer and sparser punctation on the dorsum of the mesosoma in cupreus is usually consistent, particularly the pronotum, but one of the Magdalena specimens has the punctures on the scutum and scutellum about as in fuscipennis.

\section{Paramasaris fuscipennis Cameron}

P. fuscipennis Cameron, 1901: 312, ㅇ (BMNH)_-"Santa Fé Mountains, New Mexico."

Zethoides flavolineatus Cameron, 1904: 94, ồ (BMNH)—“Panama (Pacific side)." 
The statement of the type locality as being in New Mexico is perhaps an error. As Bradley (1922:387) put it: "I have not been able to learn of any mountains bearing this name." There is a Santa Fé mountain in Jalisco in Mexico $\left(20^{\circ} 30^{\prime} \mathrm{N}, 103^{\circ} 02^{\prime} \mathrm{W}\right)$, and this species has been later collected in other parts of Mexico, but never in the United States. Krombein (1979) did not include this species in the revised Catalog of Hymenoptera north of Mexico. Besides the types, I have seen specimens from Guatemala: S. Geronimo (Champion) (BMNH and one now in MCZ); "Mexico: Jalisco, Chamela, IX-26-1985, ex. Nissolia (R. J. McGinley)" USNM; "Sinaloa, 5 mi. NW Choix, VIII-27 and 31, and IX-5-1968 (T. A. Sears, R. C. Gardner \& C. S. Glaser)" UCD and MCZ. It has also been recorded from Colombia: Bogotà by Zavattari (1912; confirmed by Giordani Soika, 1974).

Genus Gayella Spinola, 1851: 328. Type species Gayella eumenoides Spinola, 1851. Monotypic.

Eumenoides group

Gayella eumenoides Spinola

G. eumenoides Spinola, 1851:333, pl. II, fig. 2, 충 (lectotype $\widehat{\jmath}$ MNHN, designated by Giordani Soika, 1974:98) - Chile, "provincias del norte y sobretodo en Santa Rosa."

G. sicheliana Schulthess, 1910: 189. As a synonym of eumenoides, attributed to Saussure.

Common in central Chile, this species has also been recorded from Argentina: Mendoza by Brèthes (1903) and following him various authors; however, Willink (1956) considered this record dubious. I have seen specimens from Aconcagua, Atacama, Coquimbo, Curicó, Maule, O'Higgins, Santiago and Valparaíso.

Bequaert and Ruiz (1942) summarized early literature on this species. Reed (1893) pointed out that Spinola had confused the sexes in the original description, and Willink (1956) observed that Spinola and Saussure confused eumenoides and araucana. This is the only gayelline for which any behavioral information has been published, by Claude-Joseph (1930). It provisions clusters of free mud cells with nectar.

Gayella araucana Willink

G. araucana Willink, 1956:341, 342, 346, figs. 3, 4, 우 (type 우 IPC)—“Chile, Prov. Santiago: Renca." 
I have seen specimens from Aconcagua, Atacama, Coquimbo, O'Higgins, Santiago (including paratypes from BMNH and IML) and Talca. Willink and Ajmat de Toledo (1979) recorded this species from Bío-Bío.

Willink and Ajmat de Toledo (1979) recognized the same species groups as the present paper, but stated that araucana is the most distinct and should possibly be treated as a different genus. They even stated that morphologically it approaches eumenines of the genera Ancistrocerus and Stenodynerus, but it does not possess any of the synapomorphies of that subfamily (Carpenter, 1981). The characters cited as distinguishing araucana are only trivially different from other Gayella. These characters comprise the mesosoma with lateral margins subparallel, the malar space nearly obliterated, the form of the emargination of male metasomal tergum VII and the form of the male genitalia. The condition of the malar space is primitive, and similar to eumenoides (cf. Figs. 15 and 16); the emargination of male tergum VII is little different from that of eumenoides (cf. Figs. 51 and 52). As noted above, their figures of the male genitalia are misleading; araucana is no more different in the digitus or aedeagus than the other species are from each other (Figs. 57-61, 63). The cuspis is autapomorphic in having a sharp tubercle, but this again is not properly illustrated in the other species, all of which have some projection. The subparallel mesosoma is also autapomorphic, but this is a minor difference compared to the outstanding similarities shared by all species of Gayella. Placement of araucana in a separate genus would render Gayella paraphyletic, which is reason enough to reject doing so.

\section{Mutilloides group}

Gayella reedi Willink

G. reedi Willink, 1963:385, 1 fig., 우 (CAS) - “Casa Blanca, Valparaíso, Chile."

I have seen material from Atacama, Coquimbo (including a USNM paratype) and Valparaíso (including CAS and IML paratypes). The male has not previously been described. One specimen labelled "Chile, Coquimbo: Llano de la Higuera, N. of La Serena, Sept. 29, 1980 Luis E. Peña" AMNH, and two from "Chile: Atacama $20 \mathrm{~km}$. E on Ruta $31 \mathrm{nr}$. Puquios, 9-X-1984 (C. Porter \& T. O'Neill)" CP and MCZ, evidently belong to this species. The pilosity is the same as in the female (Fig. 36). The color markings are also 

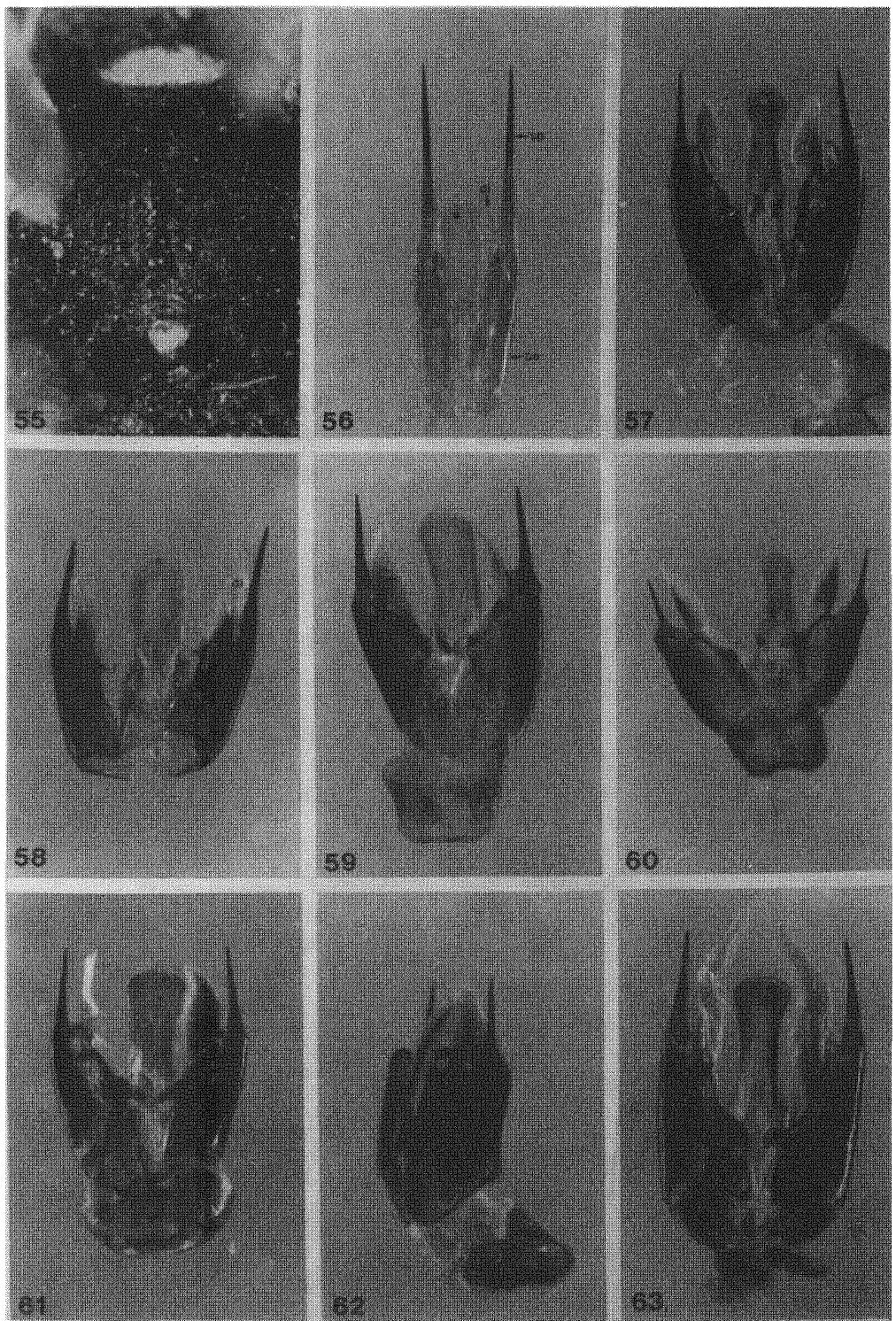

Figs. 55-63. 55. Gayella patagonica $\$$, 11X. Posterodorsal view of propodeum. 56-63. Male genitalia. 56-61. Ventral view. 56. Paramasaris fuscipennis, 26X. 57. G. eumenoides, $17 \times$. 58. G. araucana, $21 \times$. 59. G. reedi, $18 \times$. 60. G. pata- 
identical, except that the clypeus is whitish (Fig. 17); the scutellum is completely black (often with some white in females). The clypeus is longer than wide and weakly pointed, the mandibles are tridentate, the postocular carina is very short, the malar space is about $1 / 2$ the width of the interantennal distance, the pronotum projects very slightly, the first metasomal tergum is about $11 / 3$ as long as wide, and sternum II has traces of posterolateral ridges. The genitalia are illustrated in Fig. 59.

\section{Gayella mutilloides Saussure}

G. mutilloides Saussure, 1855: 114, \& (BMNH)-“Le Chili."

G. odyneroides Schulthess, 1910: 189. Lapsus for mutilloides.

G. mutilloides nigerrima Giordani Soika, 1960 (1958): 80, 우 (Giordani Soika coll.)_-Cile."

The synonymy was established by Bequaert and Ruiz (1942) and Willink (1963). Willink (1956) described the male, and recorded the species from Argentina: Chubut and Neuquén. In addition to the holotype of mutilloides, I have seen material from Chile: Nuble, ?Valdivia (CAS), and "El Manzano" (MCZ); and Argentina: Rio Negro. It has also been recorded from Aconcagua and Malleco by Willink and Ajmat de Toledo (1979).

\section{Gayella patagonica Willink}

G. patagonica Willink, 1956:341, 342, 350, figs. 9, 10, 11, 우수 (type 우 IML)_"Esquel, Chubut, Argentina."

G. cerceroides Giordani Soika, 1960 (1958):82, \& (BMNH)—“N. W.

Patagonia, 1000-3000 piedi."

The synonymy was established by Willink (1963), who also recorded this species from Chile: Lo Valdés, Cordillera de Santiago $2500 \mathrm{~m}$ (stated to be in the MCZ but not there; Willink and Ajmat de Toledo, 1979, cite what is evidently this specimen as in IML). In addition to the holotype of cerceroides, I have seen specimens from Argentina: Chubut (including a paratype from MF) and Rio Negro,

gonica, 11×. 61. G. mutilloides, 13X. 62. G. mutilloides, 13X. Lateral view. 63. G. luispenai, $15 \times$. Ventral view. a: aedeagus; di: digitus; cu: cuspis; $n g$ : narrowing of propodeal median groove; $p a:$ paramere; $p l$ : dorsal parameral lobe; $s p$ : parameral spine; $t$ : tubercle of cuspis. 
as well as the BMNH paratypes from "N. W. Patagonia." Willink and Ajmat de Toledo (1979) also mention a Mendoza record.

\section{Gayella luispenai Willink and Ajmat de Toledo}

G. luispenai Willink and Ajmat de Toledo, 1979: 427, 428, 429, figs.

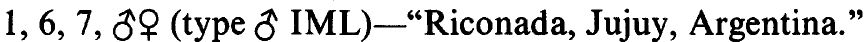

I have seen two specimens, a male from Jujuy, Est. Iturbe 17-I1979 (L. Fidalgo) and a female from Mendoza, Uspallata 5.XII.1979 (A. Roig). This species was also recorded from Bolivia: Potosí by Willink and Ajmat de Toledo (1979).

This species is very similar to patagonica, as noted by Willink and Ajmat de Toledo (1979:430). Most of the characters they cite will not distinguish females. The series of patagonica I have seen from Rio Negro (MF) overlaps in size, length of the malar space and development of protuberances on female metasomal sternum II. The punctation tends to be less coarse on the scutellum of patagonica, but this varies among the specimens. The propodeal median groove will separate them (Figs. 45,55 ), but as I have seen only one female of luispenai, I cannot be certain that this feature does not vary. Males are readily distinguished by the sternal projections in luispenai (Fig. 54).

\section{BIOGEOGRAPHY}

It is clear from the few records for some species that their distributions are very poorly known, and further collecting, particularly of Paramasaris, will doubtless extend the ranges of some of these. Nevertheless, a few remarks about biogeography may be made. Paramasaris and Gayella occupy completely different regions, Tropical American versus Patagonia, which corresponds to a well-known vicariant break. Within Gayella, most of the species overlap broadly in distribution. The clade mutilloides + patagonica + luispenai is the only group which occurs on the eastern side of the Cordillera, but the first two species are also found in Chile. By contrast, Paramasaris shows a pattern of endemism. Within the genus, the distribution of the sister-species fuscipennis and cupreus is basically trans-Andean: Central America versus western Amazonia. There is a record of cupreus from the western side of the Sierra de Perijá, but this was elevated in the late Oligocene (Kellogg, 1984). In turn, the sister-group of this clade, brasiliensis, is southeastern Brazil, and the sister-group of all three species, richardsi, is southern Amazon 
basin. This pattern does not correspond to that shown by the avifauna, for example Cracraft and Prum (1988), where southeastern Brazil is not closely related to a western Amazon/trans-Andean clade. However, that study showed southeastern Brazil as a composite area, implying either dispersal or differing ages for components of the regional biota. The latter factor may well explain the incongruence; Gayellini is an ancient group, since the Masarinae as a whole is gondwanian (Carpenter, 1981).

\section{ACKNOWLEDGMENTS}

I am grateful to Arnold Menke and Abraham Willink for critically reading the manuscript, and Mick Day for assistance at the British Museum. Amy B. Wright provided the habitus drawing. This research was supported by a Milton Fund grant and NSF grant BSR-850855 to the author.

\section{SUMMARY}

The phylogenetic relationships of the gayelline wasps are investigated using cladistic methods. Paragayella is the sister-group of Paramasaris, and is synonymized with that genus. This taxon is the sister-group of Gayella. Cladograms are presented for the species in each genus, along with keys and distributional notes.

\section{Literature Cited}

Ashmead, W. A.

1902a. Classification of the fossorial, predaceous and parasitic wasps, or the superfamily Vespoidea. Paper no. 7. Family XXIX. Eumenidae. Can. Ent. 34: 203-210.

1902b. Classification of the fossorial, predaceous and parasitic wasps, or the superfamily Vespoidea. Paper no. 8. Family XXX. Masaridae. Can. Ent. 34: 219-221.

BEQUAERT, J.

1918. A revision of the Vespidae of the Belgian Congo based on the collection of the American Museum Congo Expedition, with a list of Ethiopian diplopterous wasps. Bull. Am. Mus. Nat. Hist. 39: 1-384.

1928. A study of certain types of diplopterous wasps in the collection of the British Museum. Ann. Mag. Nat. Hist. (10)2: 138-176.

Bequaert, J. AND F. P. Ruiz

1942 (1940). A revision of the Vespidae (Hymenoptera, Diploptera) of Chile. Part 1. Subfamilies Gayellinae and Zethinae. Rev. Chilena Hist. Nat. 44: 214-223. 
Bradley, J. C.

1922. The taxonomy of the masarid wasps, including a monograph on the North American species. Univ. Calif. Publ. Ent. 40: 1-208.

BRETHES, J.

1903. Los euménidos de las Repúblicas del Plata. An. Mus. Nac. Buenos Aires (3a)2(9): 231-320.

Cameron, $P$.

1901. Description of a new genus and five new species of aculeate Hymenoptera from the Santa Fé Mountains, New Mexico. Trans. Am. Ent. Soc. 27: 311-316.

1904. Description of a new genus and of four new species of Hymenoptera. Trans. Am. Ent. Soc. 30: 93-96.

1905. Description of a new genus and species of Braconidae from Cape Colony. Entomol. 38: 268-269.

Carpenter, J. M.

1981 (1982). The phylogenetic relationships and natural classification of the Vespoidea (Hymenoptera). Syst. Ent. 7: 11-38.

1987. Phylogenetic relationships and classification of the Vespinae (Hymenoptera: Vespidae). Syst. Ent. 12: 413-431.

1988. The phylogenetic system of the Stenogastrinae (Hymenoptera: Vespidae). J. New York Ent. Soc. 96: 140-175.

1989. Phylogenetic relationships and the origin of social behavior in the Vespidae. In Ross, K. G. and R. W. Matthews, eds., The Social Biology of Wasps. Cornell Univ. Press (in press).

Carpenter, J. M. And J. M. Cumming

1985. A character analysis of the North American potter wasps (Hymenoptera: Vespidae; Eumeninae). J. Nat. Hist. 19: 877-916.

Claude-Joseph, F. (H. Janvier)

1930. Recherches biologiques sur les prédateurs du Chili. Ann. Sci. Nat. Bot. Zool. (10)13: 235-254.

Cracraft, J. and R. O. Prum

1988. Patterns and processes of diversification: Speciation and historical congruence in some neotropical birds. Evol. 42: 603-620.

Cresson, E. T.

1879. Untitled. Trans. Am. Ent. Soc. 7 (Proc.): vi-vii.

Fox, W. J.

1899. Contributions to a knowledge of the Hymenoptera of Brazil, No. 7 -Eumenidae (Genera Zethus, Labus, Zethoides, Eumenes, Montezumia and Nortonia). Proc. Acad. Nat. Sci. Philadelphia 51: 407-464.

Giordani Soika, A.

1960 (1958). Notulae Vespidologicae. Boll. Mus. Civ. Ven. 11: 35-102.

1974. Revisione della sottofamiligia Gayellinae (Hym. vesp.). Boll. Mus. Civ. Ven. 25: 87-106.

HenNig, W.

1966. Phylogenetic systematics. Univ. Illinois Press, Urbana. 
Kellogg, J. N.

1984. Cenozoic tectonic history of the Sierra de Perijá, Venezuela-Colombia, and adjacent basins. Mem. Geol. Soc. Amer. 162: 239-261.

Krombein, K. V.

1979. Vespoidea. pp. 1469-1522 In Krombein et al. (eds.), Catalog of Hymenoptera in America north of Mexico. Smithson. Inst. Press, Washington, D.C.

ReED, E. C.

1893. Entomolojía Chilena. Sinöpsis de las avispas Chilenas de la familia “Odyneridae." An. Univ. Chile (Mem. Cient. Lit.) 84: 873-897.

RICHARDS, $\mathbf{O}$. W.

1962. A Revisional Study of the Masarid Wasps (Hymenoptera, Vespoidea). Brit. Mus. (Nat. Hist.), London.

1973. The subgenera of Polistes Latreille (Hymenoptera, Vespidae). Rev. Bras. Ent. 17: 85-104.

1978. The social wasps of the Americas excluding the Vespinae. Brit. Mus. (Nat. Hist.), London.

SAUSSURE, H. F. DE.

1852-1858. Études sur la Famille des Vespides, Vols. 1-3. V. Masson, Paris and J. Cherbuliez, Geneva.

SCHULthesS ReChBERG, A. W.

1910. Uber einige neue und weniger bekannte Eumeniden (Vespiden, Hymenoptera). Dts. Ent. Z.: 187-192.

Schulz, W. H.

1906. Spolia Hymenopterologica. Paderborn.

SNelling, R. R.

1986. The taxonomy and nomenclature of some Australian paragiine wasps SPINOLA, M. (Hymenoptera: Masaridae). Contrib. Sci. 378: 1-19.

1851. Fauna Chileana. Insectos. Orden VII. Himenopteros. In Gay, C. Historia fisica y politica de Chile. Zoologia 6: 153-569.

WiLEY, E. 0.

1979. An annotated Linnaean hierarchy, with comments on natural taxa and competing systems. Syst. Zool. 28: 308-337.

Willink, A.

1956. Las especias del genero Gayella Spinola (Hym. Gayellinae). Bol. Acad. Nac. Cienc. 39: 340-352.

1963. Una nueva especie de Gayella y observaciones sobre otras (Hym., Masaridae: Gayellinae). Acta Zool. Lilloana 19: 385-390.

Willink, A. AND M. Del. V. Ajmat de Toledo.

1979. Una nueva especie de Gayella (Hym., Masaridae: Gayellinae). Acta Zool. Lilloana 35: 427-434.

\section{ZAVATTARI, E.}

1912. Bemerkungen über die Neotropischen Masariden. Arch. Naturgesch. 78A(2): 58-65. 

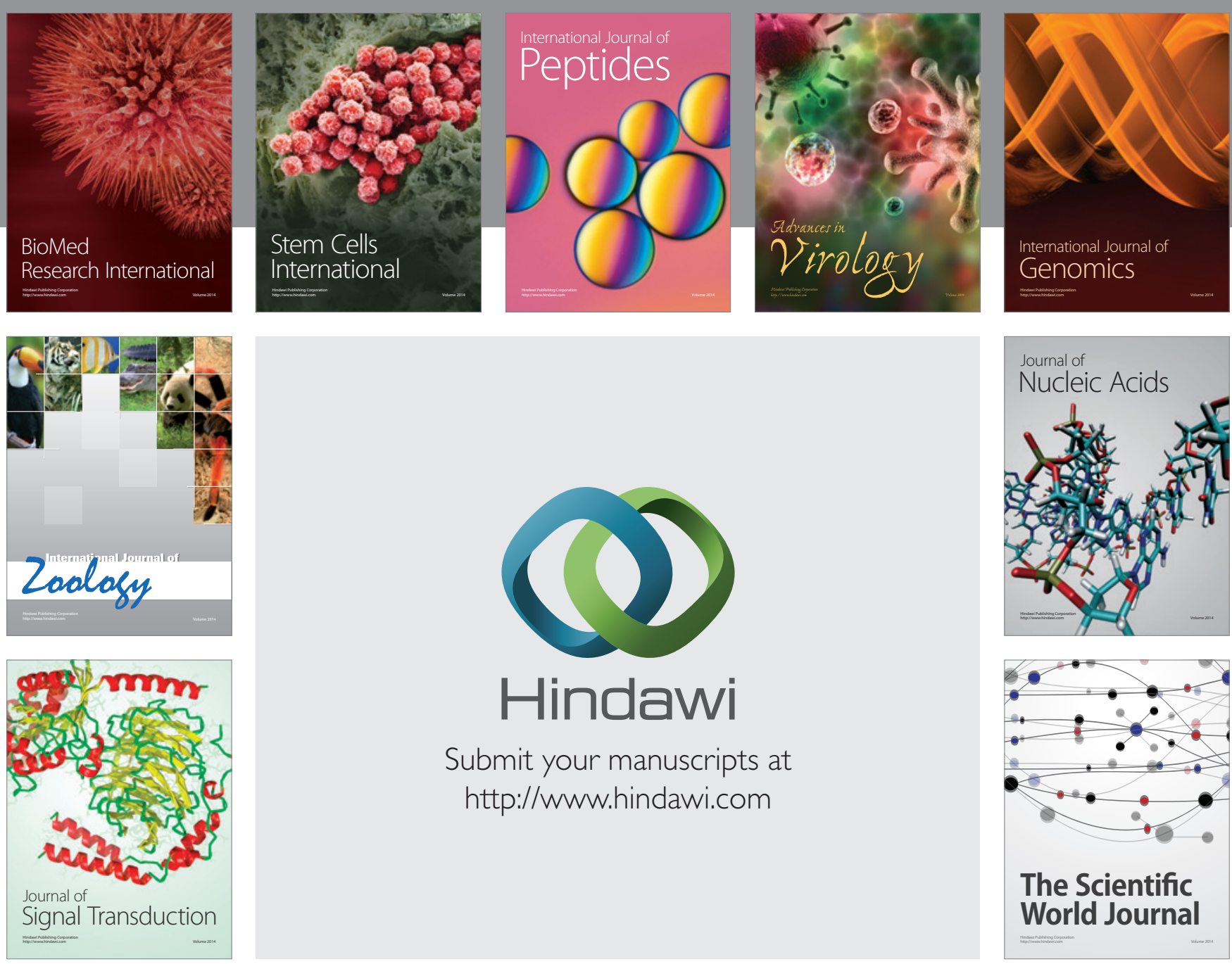

Submit your manuscripts at

http://www.hindawi.com
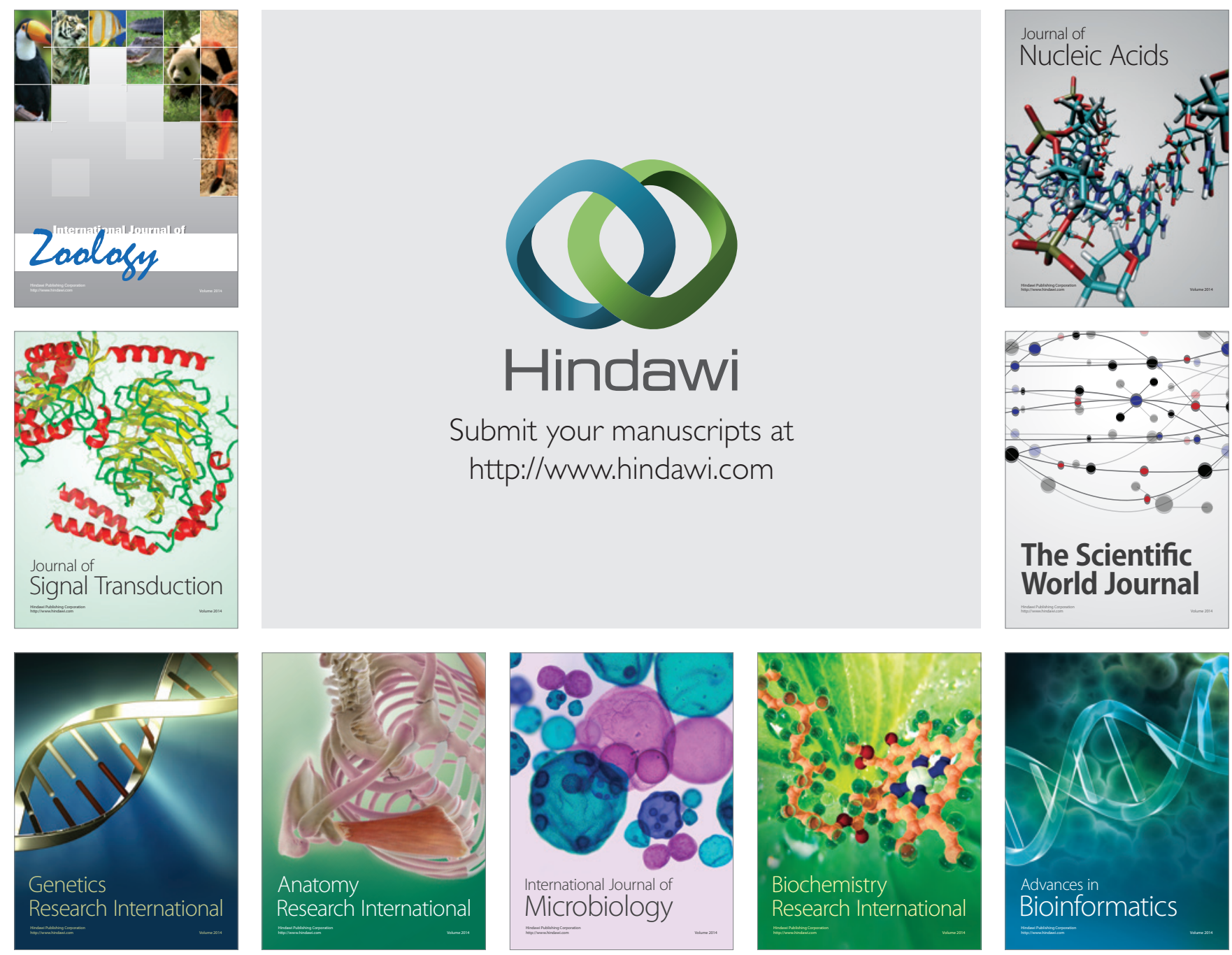

The Scientific World Journal
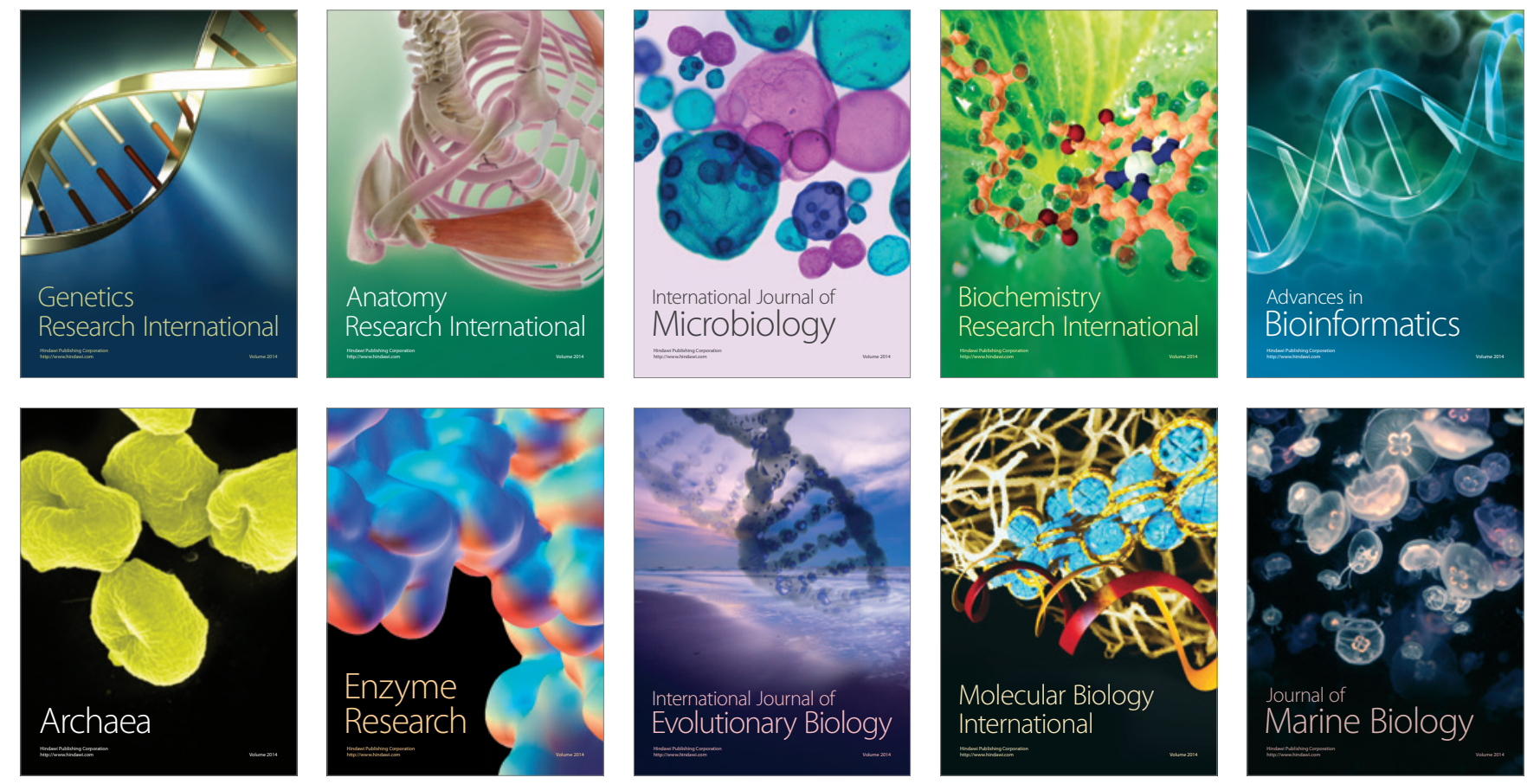